International Conference on Research in Education, Teaching and Learning

Paris, France| November 2 -4, 2018

\title{
Factors Responsible For the Under-Representation of Women in Senior High School Headship in the Brong Ahafo Region, Ghana
}

\author{
Kusi, $\mathrm{H}$.
}

Department of Educational Administration and Management, Faculty of Educational

Studies, University of Education, Winneba, Ghana

\begin{abstract}
The study explored the factors responsible for the under-representation of women in Senior High School headship in selected districts and municipalities in the Brong Ahafo region of Ghana. This was a qualitative study underpinned by the interpretive paradigm. Specifically, a case study design was employed for the study. The sample for the study consisted of 7 purposively selected headmistresses of the schools in the region. A semistructured interview was employed for data collection and the collected data was analysed thematically. The study revealed that reluctance of female-teachers to accept responsibilities delegated to them, unfavourable and discriminatory leadership recruitment and hiring practices, female teachers' failure to have career development plans that include headship, and lack of support for women to win competition for leadership positions in the schools were among the factors responsible for their underrepresentation in headship. Among others, the study concluded that a combination of factors, including those relating to the organizations accounted for the low representation of women in headship in the region. Therefore, it was recommended that, for the women to progress to headship, the secondary schools should collaborate with the various education directorates in the region to organize training programmes to equip potential female leaders with leadership skills, and to help them plan their careers to include school headship.
\end{abstract}

Keywords: School leadership, Headship, Female teachers, Under-representation, Women, Senior High School. 
